Article

\title{
Properties of Titanium Oxide Coating on MgZn Alloy by Magnetron Sputtering for Stent Application
}

\author{
Shusen Hou ${ }^{1,2}$, Weixin $\mathrm{Yu}^{2}$, Zhijun Yang ${ }^{2}$, Yue $\mathrm{Li}^{2}$, Lin Yang ${ }^{1, *}$ and Shaoting Lang ${ }^{2}$ \\ 1 School of Chemistry and Chemical Engineering, Henan Normal University, Xinxiang 453007, China; \\ shusen.hou@xxu.edu.cn \\ 2 School of Mechanical and Electrical Engineering, Xinxiang University, Xinxiang 453003, China; \\ yuweixin@xxu.edu.cn (W.Y.); yangzhijun@xxu.edu.cn (Z.Y.); liyue@xxu.edu.cn (Y.L.); \\ shaotinglang@xxu.edu.cn (S.L.) \\ * Correspondence: yanglin1819@xxu.edu.cn; Tel.: +86-373-3328117
}

Received: 14 September 2020; Accepted: 16 October 2020; Published: 19 October 2020

\begin{abstract}
Constructing surface coatings is an effective way to improve the corrosion resistance and biocompatibility of magnesium alloy bioabsorbable implants. In this present work, a titanium oxide coating with a thickness of about $400 \mathrm{~nm}$ was successfully prepared on a MgZn alloy surface via a facile magnetron sputtering route. The surface features were characterized using scanning electron microscopy (SEM), atomic force microscopy (AFM), X-ray diffraction (XRD), X-ray photoelectron spectroscopy (XPS), and the contact angle method. The corrosion behavior and biocompatibility were evaluated. The results indicated that the amorphous $\mathrm{TiO}_{2}$ coating with a flat and dense morphology was obtained by magnetron-sputtering a titanium oxide target. The corrosion current density decreased from 1050 (bare $\mathrm{MgZn}$ alloy) to $49 \mu \mathrm{A} / \mathrm{cm}^{2}$ (sample with $\mathrm{TiO}_{2}$ coating), suggesting a significant increase in corrosion resistance. In addition, the $\mathrm{TiO}_{2}$ coating showed good biocompatibilities, including significant reduced hemolysis and platelet adhesion, and increased endothelial cell viability and adhesion.
\end{abstract}

Keywords: titanium oxide; magnetron sputtering; magnesium alloy; corrosion resistance; biocompatibility

\section{Introduction}

Magnesium alloy (Mg alloy) is an excellent biological material for bioabsorbable implant applications, due to its low corrosion resistance, good biocompatibility, and mechanical properties [1,2]. In recent years, cardiovascular stents made from absorbable $\mathrm{Mg}$ alloys have been developed to overcome the drawbacks of permanent metallic stents, including late-term restenosis, delayed re-endothelialization, and persistent inflammation [3,4]. However, the main disadvantage of $\mathrm{Mg}$ alloys for medical applications is the rapid and inhomogeneous corrosion in the physiological environment; hence, $\mathrm{Mg}$ alloy implants may lose their mechanical integrity before the complete healing of the tissue. In order to solve this problem, surface modifications have been widely carried out to prepare suitable coatings onto $\mathrm{Mg}$ alloys as corrosion protective layers, and also to improve their biocompatibility and mechanical stability [5-9]. Therefore, modifying the surface with ideal coatings is of high significance for $\mathrm{Mg}$ alloy stents.

For Mg alloy cardiovascular stents, some organic-based coatings, such as polylactic acid (PLA) [7], polydopamine (PDA) [10,11], poly (lactic-co-glycolic acid) (PLGA) [12], and polytrimethylene carbonate (PTMC) [13], have been commonly used as corrosion protection layers or drug delivery carriers to prevent the in-stent restenosis (ISR). However, the adhesion of organic coatings still needs to be improved. On the other hand, inorganic coatings can be prepared by various methods, providing a superior adhesion with substrates. More importantly, inorganic coatings are remarkably 
corrosion-resistant, and thus, they should be suitable for $\mathrm{Mg}$ alloy stents to improve the rapid corrosion behavior. Some inorganic coatings including magnesium fluoride $\left(\mathrm{MgF}_{2}\right)[14]$ and titanium dioxide $\left(\mathrm{TiO}_{2}\right)[15,16]$ have been used to endow the $\mathrm{Mg}$ alloy with greater corrosion resistance and improved biocompatibility.

It is well known that titanium oxide is chemically stable, and the biocompatibility of a titanium oxide coating has been demonstrated [17-19]. In a representative literature, Huang et al. [20] synthesized titanium oxide film on a cobalt alloy by ion beam-enhanced deposition at below $180^{\circ} \mathrm{C}$, and proved that titanium oxide was an excellent blood contact material because of the semiconductor nature. In our previous studies, the anatase titanium dioxide coating with sheet-like nanoscale features was fabricated via the solvothermal route at $160{ }^{\circ} \mathrm{C}$, which improved the corrosion resistance of degradable MgZn alloy [21].

In view of the current research status and progress, there is still a lack of comprehensive evaluation on the application prospects of the titanium oxide-coated absorbable $\mathrm{Mg}$ alloy stent. In this paper, titanium oxide was prepared on $\mathrm{Mg}$ alloy substrates at room temperature by a facile and clean magnetron sputtering. The comprehensive properties including corrosion resistance, blood compatibility, and endothelial cells (ECs) adhesion of the as-prepared coating were discussed.

\section{Materials and Methods}

\subsection{Preparation of the Coating}

In the current study, titanium oxide coatings were deposited onto the surface of biomedical MgZn alloy (composition: $2.0 \mathrm{wt} . \% \mathrm{Zn}, 0.46 \mathrm{wt} . \%$ Y, $0.5 \mathrm{wt} . \% \mathrm{Nd}$, balance Mg), developed by Zhengzhou University, China [12,22]. Firstly, rectangular samples with dimensions of $10 \times 10 \times 1 \mathrm{~mm}^{3}$ were cut from the as-cast MgZn ingots by wire-electrode machining, then mechanically polished and sonicated in ethanol for $5 \mathrm{~min}$. Finally, samples were dried before magnetron sputtering. Titanium oxide was deposited on the $\mathrm{MgZn}$ samples for $2 \mathrm{~h}$, with a radio-frequency magnetron sputtering system by sputtering a high-purity $\mathrm{TiO}_{2}$ target under a constant power of $150 \mathrm{~W}$. The working pressure was $0.6 \mathrm{~Pa}$ with an argon flow of $30 \mathrm{sccm}$.

\subsection{Characterizations}

The characteristics of the as-prepared coatings were analyzed by a scanning electron microscope (SEM, Hitachi SU8000, Tokyo, Japan), energy-dispersive spectrometer (EDS), and atomic force microscope (AFM, Bruker MultiMode8, Billerica, MA, USA). The crystal structure was determined by employing an X-ray diffractometer (XRD, PANalytical X'Pert3 Powder, Malvern Instruments, Malvern, UK) with $\mathrm{Cu} \mathrm{K} \alpha$ radiation at $45 \mathrm{kV}$ and $40 \mathrm{~mA}$. The valence states of the elements were detected using an X-ray photoelectron spectrometer (XPS). The water contact angle (CA) of samples $(n=3)$ was measured with $10 \mu \mathrm{L}$ droplets of deionized water at ambient temperature, using a contact angle meter.

\subsection{Corrosion Tests}

For corrosion tests, bare and Ti-O-coated MgZn samples $(n=3)$ were immersed in simulated body fluids (SBFs, containing $8.035 \mathrm{~g}$ of $\mathrm{NaCl}, 0.355 \mathrm{~g}$ of $\mathrm{NaHCO}_{3}, 0.225 \mathrm{~g}$ of $\mathrm{KCl}, 0.231 \mathrm{~g}$ of $\mathrm{K}_{2} \mathrm{HPO}_{4} \cdot 3 \mathrm{H}_{2} \mathrm{O}$, $0.311 \mathrm{~g}$ of $\mathrm{MgCl}_{2} \cdot 6 \mathrm{H}_{2} \mathrm{O}, 40 \mathrm{~mL}$ of $1.0 \mathrm{M}-\mathrm{HCl}, 0.292 \mathrm{~g}$ of $\mathrm{CaCl}_{2}, 0.072 \mathrm{~g}$ of $\mathrm{Na}_{2} \mathrm{SO}_{4}$, and $6.118 \mathrm{~g}$ of $\mathrm{Na}_{2} \mathrm{HPO}_{4}$, in $1000 \mathrm{~mL}$ of deionized water, $\mathrm{pH}=7.4,37^{\circ} \mathrm{C}$ ) [23]. The solution volume-to-specimen area ratio was $40 \mathrm{~mL} / \mathrm{cm}^{2}$. After a decent interval, samples were rinsed with deionized water and dried. Then, the corrosion products were analyzed by SEM and XRD.

The electrochemical corrosion behavior of samples $(n=3)$ was measured through a three-electrode system (CorrTest CS2350, Corrtest Instruments, Wuhan, China). A saturated calomel electrode, platinum electrode, and the sample were respectively utilized as the reference electrode, counter-electrode, and working electrode. The polarization curve of tested samples (with a $1 \mathrm{~cm}^{2}$ area 
exposed in $150 \mathrm{~mL}$ of SBF) was measured with a scanning rate of $0.5 \mathrm{mV} / \mathrm{s}$, after a steady open-circuit potential (OCP) value was achieved.

\subsection{Biocompatibility Evaluation}

Blood compatibility was evaluated including hemolysis and platelet adhesion. The samples $(n=3)$ were put into the test tubes containing $10 \mathrm{~mL}$ normal saline at $37^{\circ} \mathrm{C}$ for $30 \mathrm{~min}$. Subsequently, $0.2 \mathrm{~mL}$ of diluted blood was added into every tube and incubated for $60 \mathrm{~min}$ at $37^{\circ} \mathrm{C}$. The solution was centrifuged at $3000 \mathrm{rpm}$ for $5 \mathrm{~min}$ and the absorbance $\left(\mathrm{OD}_{\mathrm{t}}\right)$ of the supernatant at $545 \mathrm{~nm}$ was determined by a microplate reader. Normal saline was used as a negative control $\left(\mathrm{OD}_{\mathrm{nc}}\right)$, and deionized water as a positive control $\left(\mathrm{OD}_{\mathrm{pc}}\right)$. The hemolysis ratio was calculated by the following equation:

$$
\text { Hemolysis ratio }(\%)=\frac{\mathrm{OD}_{\mathrm{t}}-\mathrm{OD}_{\mathrm{nc}}}{\mathrm{OD}_{\mathrm{pc}}-\mathrm{OD}_{\mathrm{nc}}} \times 100 \%
$$

For the platelet adhesion test, fresh human anticoagulant blood was centrifuged at $1500 \mathrm{rpm}$ for $15 \mathrm{~min}$ and the upper yellow liquid was separated to obtain platelet-rich plasma (PRP). Then, $0.5 \mathrm{~mL}$ of PRP was taken and dropped onto every sample $\left(10 \times 10 \times 1 \mathrm{~mm}^{3}, n=3\right)$ in 24-well culture plates, incubated at $37^{\circ} \mathrm{C}$ for $120 \mathrm{~min}$. After that, samples were taken out, rinsed with normal saline, and fixed with $0.2 \%$ glutaraldehyde solution for $6 \mathrm{~h}$. Finally, samples were washed with normal saline and dehydrated with $50 \%, 75 \%, 90 \%$, and $100 \%$ ethanol for $15 \mathrm{~min}$, respectively, then dried and examined by SEM.

Human umbilical vein endothelial cells (HUVECs, Ea.hy926, Cell Bank of the Chinese Academy of Sciences, Shanghai, China) were selected to evaluate the cytocompatibility. The sterilized samples $\left(10 \times 10 \times 1 \mathrm{~mm}^{3}\right)$ were put into 24-well culture plates $(n=3)$. The cells were cultured in Dulbecco's modified Eagle medium (DMEM), then digested by $0.25 \%$ trypsin and seeded on the surface of the samples at a concentration of $2 \times 10^{4}$ cells $/ \mathrm{mL}$. After incubating for 1 and $3 \mathrm{~d}, 20 \mu \mathrm{L}$ of MTT solution $\left(5 \mathrm{mg} / \mathrm{mL}\right.$ in PBS) was added to the wells for $4 \mathrm{~h}$ incubation at $37^{\circ} \mathrm{C}$, then $150 \mu \mathrm{L}$ of DMSO was added and shaken for $10 \mathrm{~min}$. The absorbance $\left(\mathrm{OD}_{\mathrm{t}}\right)$ of $100 \mu \mathrm{L}$ of supernatant in 96 -well plates was tested by a microplate reader at $490 \mathrm{~nm}$. DMEM solution with $10 \%$ serum was used as a negative control. Cell viability was calculated by the following equation:

$$
\text { Viability }(\%)=\frac{\mathrm{OD}_{\mathrm{t}}}{\mathrm{OD}_{\mathrm{nc}}} \times 100 \%
$$

To observe the adhered cells, samples were taken out and washed with PBS buffer several times, then put into PBS buffer containing $2.5 \%$ glutaraldehyde for $12 \mathrm{~h}$ at $4{ }^{\circ} \mathrm{C}$, and dehydrated in increasing concentrations of ethanol. After drying and spraying with gold, the cell morphology on the surface of samples was observed by SEM.

\section{Results and Discussion}

\subsection{Coating Characteristics}

Figure $1 \mathrm{a}, \mathrm{b}$ present the surface and cross-sectional microstructure of the $400 \mathrm{~nm}$-thick titanium oxide coating deposited on the MgZn substrate after $2 \mathrm{~h}$ of magnetron sputtering. The obtained coating was flat macroscopically but slightly rough on the microscopic level. There is a clear boundary visible in the SEM image between the substrate and the coating. This is determined by the sputtering process. Under the action of the electric field, the electrons collide with argon atoms in the process of flying to the substrate, which makes them ionize to produce $\mathrm{Ar}^{+}$ions and new electrons. The new electrons fly to the substrate, and $\mathrm{Ar}^{+}$ions accelerate to fly to the cathode $\mathrm{TiO}_{2}$ target and bombard the target surface with high energy to make the target sputtering. The sputtered neutral target molecules, i.e., $\mathrm{TiO}_{2}$, deposited and gathered more and more on the substrate to form a thin coating in the form of nanoparticles. According to the results of AFM measurement, as shown in Figure 2c, 
the particle size was $\sim 100 \mathrm{~nm}$ and the coating showed a smooth surface with a roughness $\left(R_{\mathrm{a}}\right)$ of 51 $\mathrm{nm}$. The micro-characteristic of the coating caused a change in the surface water contact angle (CA), from $8.4^{\circ}$ of the polished $\mathrm{MgZn}$ substrate to $79.6^{\circ}$ after magnetron sputtering, indicating a decreased hydrophilicity, as shown in Figure $2 a, b$.

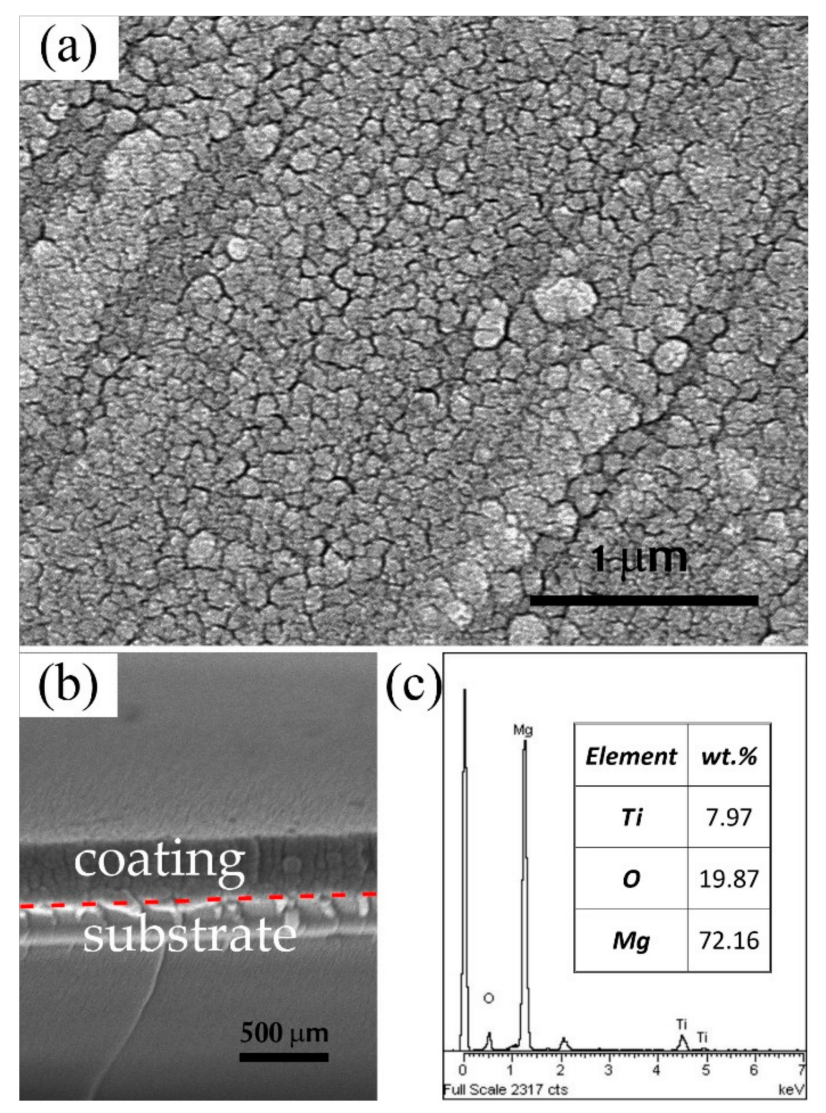

Figure 1. SEM morphologies of (a) surface and (b) cross-sectional microstructures, and (c) the EDS spectra of the titanium oxide-coated MgZn alloy.

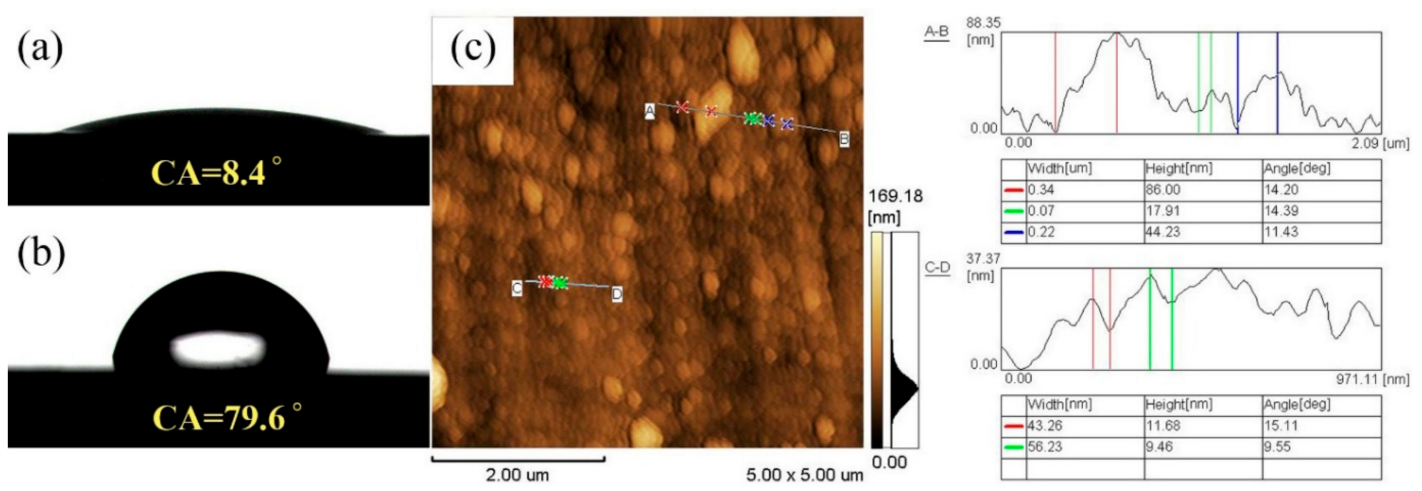

Figure 2. The contact angles of the (a) $\mathrm{MgZn}$ substrate, (b) $\mathrm{TiO}_{2}$ coating, and (c) the AFM micrograph of the $\mathrm{TiO}_{2}$ coating.

In Figure 1c, $\mathrm{Ti}$ and $\mathrm{O}$ were detected in the coating by EDS, which confirmed the existence of the Ti-O compound. Meanwhile, the phase composition of the coating and the chemical state of Ti were investigated by XRD and XPS (see Figure 3). The result of XPS shows that all Ti in the coating exists in the form of $\mathrm{TiO}_{2}$, because the peak positions of $\mathrm{Ti} 2 \mathrm{p}_{3 / 2}$ and $\mathrm{Ti} 2 \mathrm{p}_{1 / 2}$ are 458.4 and $464.1 \mathrm{eV}$, respectively, 
which are consistent with the electronic binding peak position of $\mathrm{Ti}^{4+}$ in $\mathrm{TiO}_{2}$ [17]. Figure 3 a shows the XRD pattern of the $\mathrm{TiO}_{2}$ coating deposited on the $\mathrm{Mg}$ alloy substrate. Clear peaks are found in the XRD pattern, which are all characteristics of the $\mathrm{Mg}$ alloy substrate. In addition, there are no other diffraction peaks corresponding to the titanium dioxide. A noisy pattern proves the amorphous structure of the coating. The result shows that the structure of the $\mathrm{TiO}_{2}$ coating deposited by magnetron sputtering is amorphous at a low temperature [18].
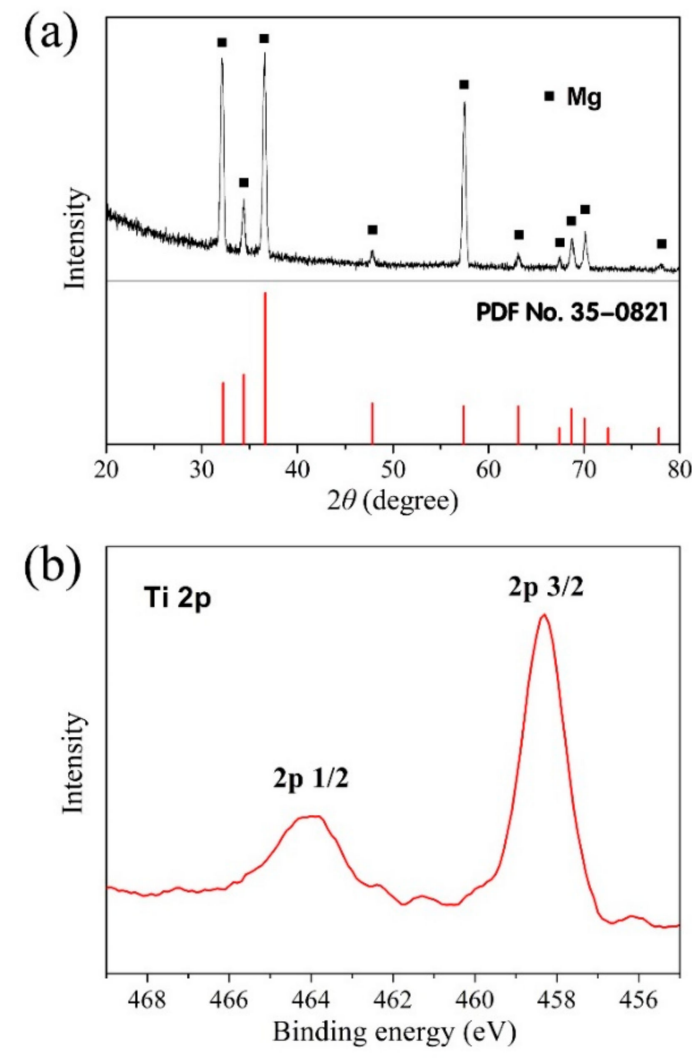

Figure 3. (a) XRD pattern of the titanium oxide coating along with the substrate and (b) XPS pattern of high-resolving Ti $2 p$ on the titanium oxide surface.

\subsection{Corrosion Behavior}

The corrosion behavior was studied by the immersion test and electrochemical technique. The surface micrographs of the bare and $\mathrm{TiO}_{2}$-coated $\mathrm{Mg}$ alloys after $14 \mathrm{~d}$ immersion in SBF are shown in Figure 4a,b respectively. The surface of the bare $\mathrm{MgZn}$ sample is heavily corroded, with abundant corrosion products deposited. It has been evidenced that during the corrosion process of $\mathrm{Mg}$ alloys, insoluble $\mathrm{Mg}(\mathrm{OH})_{2}$ is formed and falls off the surface of the matrix gradually with time, leaving an uneven surface morphology [14]. By contrast, the corrosion extent of the $\mathrm{TiO}_{2}$-coated sample is obviously lesser than that of the substrate. It can be seen that the surface was flat and the corrosion products were smaller and discontinuous. In fact, the better corrosion resistance is mainly conditional on the chemical stability of the $\mathrm{TiO}_{2}$ coating. In Figure $4 c$, it was observed that the uncorroded area is where the $\mathrm{TiO}_{2}$ coating remains, even if the coating has been broken and incomplete. The results prove that the $400 \mathrm{~nm}$-thick $\mathrm{TiO}_{2}$ coating can provide effective corrosion protection for the $\mathrm{Mg}$ alloy. The corrosion products are primarily $\mathrm{Mg}(\mathrm{OH})_{2}$, as shown in Figure $4 \mathrm{~d}$. 

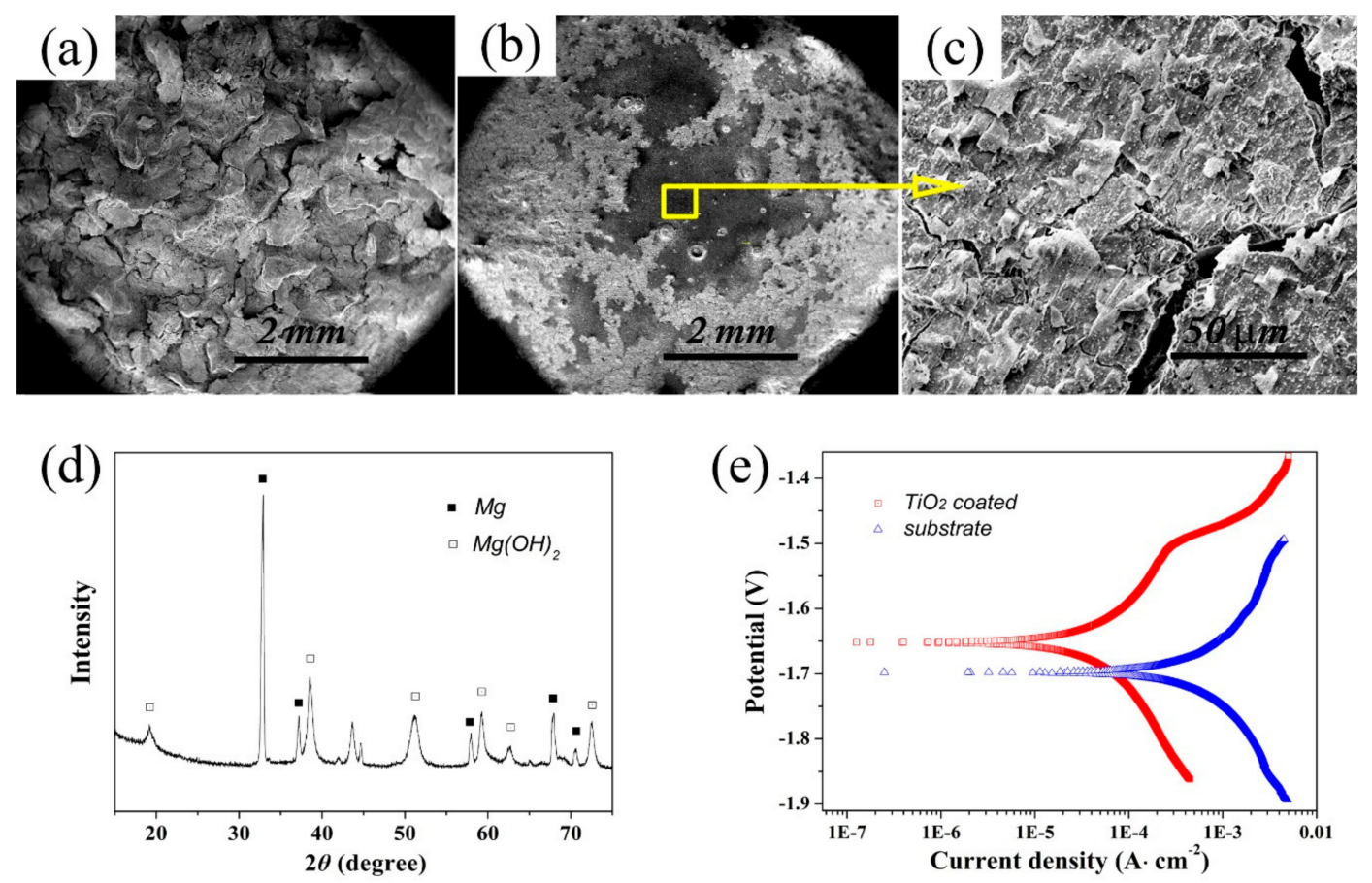

Figure 4. SEM images of (a) bare and (b,c) $\mathrm{TiO}_{2}$-coated $\mathrm{MgZn}$ samples after $14 \mathrm{~d}$ immersion in simulated body fluids (SBFs); (d) XRD pattern of corrosion products and (e) potentiodynamic polarization curves in SBF of samples (tested after the coating preparation).

A more quantitative assessment of the corrosion resistance of the $\mathrm{MgZn}$ substrate with and without the $\mathrm{TiO}_{2}$ coating was performed using potentiodynamic polarization curve measurements in $\mathrm{SBF}$, as shown in Figure 4e. From the polarization curves, the corrosion potentials $\left(E_{\mathrm{corr}}\right)$ and corrosion current densities $\left(I_{\text {corr }}\right)$ were obtained. As is known, good corrosion resistance and low corrosion rate can be reflected in a higher corrosion potential and a lowered corrosion current density. The $E_{\text {corr }}$ of the $\mathrm{MgZn}$ sample increased from -1.70 to $-1.65 \mathrm{~V}$ after the $\mathrm{TiO}_{2}$ coating deposition. The coated sample exhibited a more positive corrosion potential than the bare substrate, so the substrate will be corroded more easily than the $\mathrm{TiO}_{2}$-coated sample under the same conditions. In addition, it is found that the $I_{\text {corr }}$ of the $\mathrm{TiO}_{2}$-coated sample markedly decreased compared with that of the bare sample (i.e., 49 vs. $1050 \mu \mathrm{A} / \mathrm{cm}^{2}$ ). Hence, the constructed $\mathrm{TiO}_{2}$ coating is a superior protective layer to retard the corrosion rate of the $\mathrm{MgZn}$ substrate.

\subsection{Biocompatibility}

Materials with a poor hemolysis ratio could cause rupture of red blood cells, which may lead to thrombosis and the implantation failure. The hemolysis ratio of biomaterials in contact with blood should be less than $5 \%$. The results in Table 1 show that serious hemolysis ( $47.23 \%$, hemolysis ratio) occurred in MgZn alloys without surface treatment, while the hemolysis ratio of samples modified by the $\mathrm{TiO}_{2}$ coating was only $0.1 \%$. The anti-hemolytic property of the $\mathrm{Mg}$ alloy was significantly improved by $\mathrm{TiO}_{2}$ surface modification. Gao et al. [24] believed that the poor corrosion resistance of the unmodified magnesium alloy increased the $\mathrm{pH}$ value of the blood rapidly and promoted the combination of red blood cells and $\mathrm{Ca}^{2+}$ in the solution, finally resulting in the rupture of red blood cells and serious hemolytic reaction. The above results demonstrate that the $\mathrm{TiO}_{2}$ coating can effectively delay the corrosion of substrates and thus improve the hemolysis of $\mathrm{Mg}$ alloy. 
Table 1. List of the results of hemolysis and cytocompatibility tests.

\begin{tabular}{cccc}
\hline \multirow{2}{*}{ Samples } & \multirow{2}{*}{ Hemolysis Ratio (\%) } & \multicolumn{2}{c}{ Cell Viability (\%) } \\
\cline { 3 - 4 } & & $\mathbf{1 ~ d}$ & $\mathbf{3 ~ d}$ \\
\hline Control & - & 100 & 100 \\
Bare MgZn substrate & 47.23 & 94.1 & 89.5 \\
MgZn substrate with $\mathrm{TiO}_{2}$ coating & 0.10 & 93.4 & 94.8 \\
\hline
\end{tabular}

Platelets play an important role in promoting blood coagulation. The platelet adhesion is an essential reaction corresponding to the formation of thrombus and occlusion of arterial. Figure 5 provides the morphology of the platelets immobilized on samples. Figure 5 a shows the adhesion of platelets to $\mathrm{MgZn}$ alloy after $1 \mathrm{~h}$ of culture. The magnesium alloy surface was rapidly corroded in plasma; hence, obvious cracks can be seen after the corrosion product layer drying. In respect of the adhered platelets characteristic, a large number and serious aggregation of platelets was observed. The adhesion and aggregation of platelets will be further activated to induce thrombosis. In addition, the agglomerated platelets are likely to become fibrinogen adsorption sites, and the adsorbed fibrinogen may also lead to thrombosis. The results indicate that the unmodified Mg alloy is easy to adsorb platelets and has poor blood compatibility.
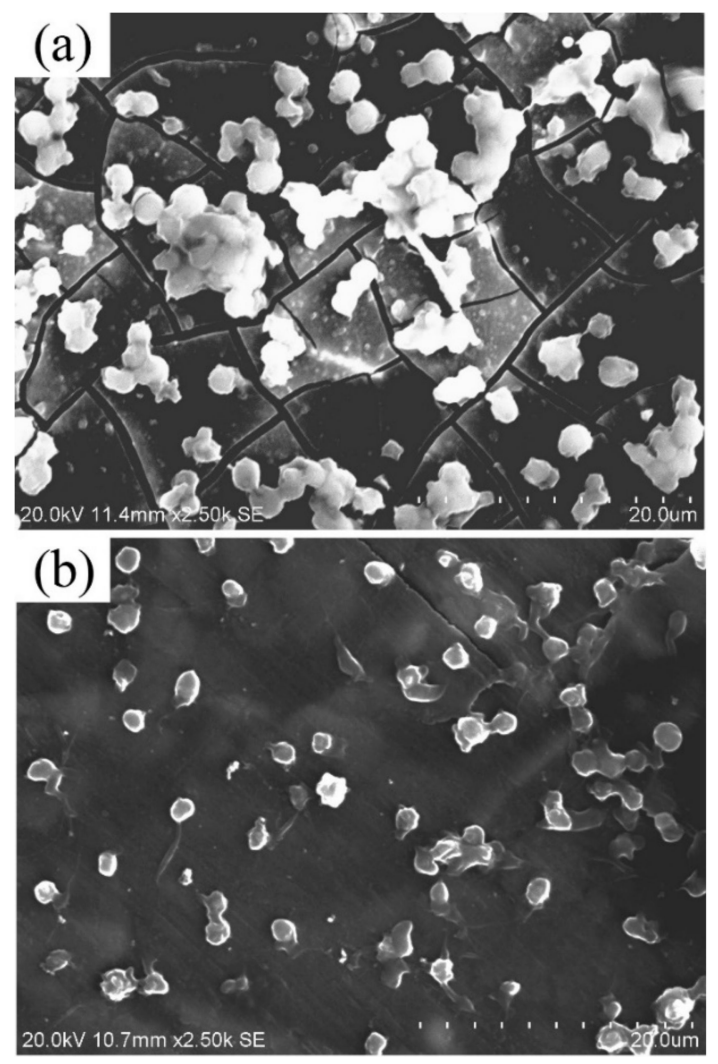

Figure 5. Typical morphology of adherent platelets on surface of (a) $\mathrm{MgZn}$ substrate and (b) $\mathrm{TiO}_{2}$ coating.

Figure $5 \mathrm{~b}$ shows the adhesion of platelets on the surface of the $\mathrm{TiO}_{2}$ coating. The corrosion resistance of the $\mathrm{MgZn}$ alloy was enhanced by surface modification, so after soaking in platelet-rich plasma for $1 \mathrm{~h}$, the sample was not corroded. Compared with the case of bare substrate, a remarkable reduced number of adhered platelets could be seen on the surface of $\mathrm{TiO}_{2}$ samples, and no agglomeration occurred. The nearly round shape and well-distributed morphology implied that the fixed platelets were not activated during the culture. The results suggest that the $\mathrm{TiO}_{2}$ coating has a better ability of anti-platelet adhesion. 
Accordingly, in consideration of the hemolysis ratio and the adsorbed platelets morphology of different samples, the $\mathrm{TiO}_{2}$-coated $\mathrm{MgZn}$ alloy not only possesses excellent properties in cutting down the hemolysis ratio but also has satisfied characteristics of not immobilizing or activating the platelets.

The $\mathrm{TiO}_{2}$-coated magnesium alloys exhibit good cytocompatibility. The viability of endothelial cells reduced in the first 3 days when exposed to the bare magnesium extract. By contrast, the cell viability of the coated group was above $90 \%$ at any time point, showing the desirable cytocompatibility, as presented in Table 1. The results could be attributed to the lower values of $\mathrm{Mg}^{2+}$ ion concentration, $\mathrm{pH}$ value, and osmolality in the extracts of $\mathrm{TiO}_{2}$-coated samples than those of bare magnesium [25]. Figure 6 shows the morphologies of Ea.hy 926 cells cultured on the coated and uncoated groups for 1 day. For the uncoated samples, no cell was observed on the surface. As for the $\mathrm{TiO}_{2}$-coated sample, it can be seen that the Ea.hy 926 cells attached and proliferated well on the sample surface, and spread in the shape of a spindle.
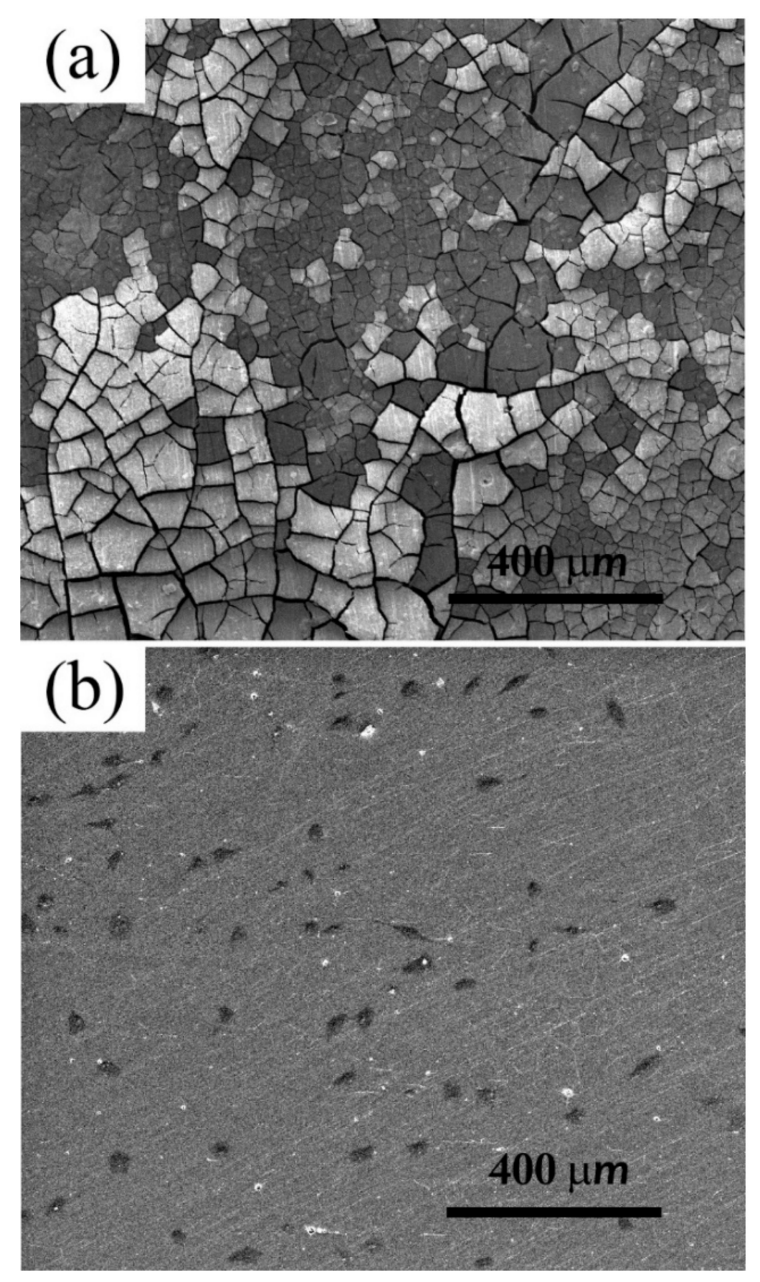

Figure 6. SEM images of Ea.hy926 cells after culturing for $1 \mathrm{~d}$ on (a) $\mathrm{MgZn}$ substrate and (b) $\mathrm{TiO}_{2}$ coating.

The endothelial cell plays a key role in constructing vascular tissue, and cell growth and endothelialization can be controlled by the surface on which it attaches [26]. Generally, a smaller contact angle can correspond to a stronger hydrophilicity of materials, which is more conducive to cell adhesion [27]. The contact angle of the $\mathrm{TiO}_{2}$-coated sample is $79.6^{\circ}$, much higher than that of the uncoated $\mathrm{MgZn}$ alloy $\left(8.4^{\circ}\right.$, see Figure $\left.3 \mathrm{a}, \mathrm{b}\right)$. However, although the uncoated $\mathrm{MgZn}$ alloy has the better hydrophilicity, the cell adhesion on the surface is poor. In this paper, the results indicated that the $\mathrm{TiO}_{2}$-coated sample was stable in the physiological environment and conducive for cell growth and proliferation. Therefore, we believe that the effect of the alkaline environment and hydrogen 
evolution by the rapid corrosion might worsen the cell adherence and spreading on the uncoated $\mathrm{Mg}$ alloy surface.

\section{Conclusions}

In this work, the titanium oxide coating was prepared on the MgZn alloy surface by magnetron sputtering. The corrosion behavior and biocompatibility have been evaluated. The major conclusions of the present work are as follows.

(1) A $400 \mathrm{~nm}$-thick titanium oxide coating with a smooth surface was deposited on the MgZn substrate after $2 \mathrm{~h}$ magnetron sputtering at room temperature. The coating was composed of dense amorphous $\mathrm{TiO}_{2}$ nanoparticles.

(2) The corrosion resistance of $\mathrm{MgZn}$ alloy was improved apparently by the $\mathrm{TiO}_{2}$ coating. After $14 \mathrm{~d}$ of immersion in $\mathrm{SBF}$, the surface of the $\mathrm{TiO}_{2}$-coated sample was less corroded than that of the substrate.

(3) The uncoated $\mathrm{Mg}$ alloys caused serious hemolysis and aggregation of platelets, whereas the $\mathrm{TiO}_{2}$-coated sample had a hemolysis ratio of less than $1 \%$ and showed a better ability of anti-platelet adhesion. The $\mathrm{TiO}_{2}$-coated $\mathrm{MgZn}$ alloy exhibited lower cytotoxicity and the endothelial cells attached well on the surface, indicating good cytocompatibility.

Author Contributions: Conceptualization, S.H. and L.Y.; methodology, S.H. and W.Y.; formal analysis, Z.Y. and S.L.; writing —original draft preparation, S.H. and Y.L.; writing—review and editing, S.H. All authors have read and agreed to the published version of the manuscript.

Funding: The research was funded by the Henan Center for Outstanding Overseas Scientists (grant no. GZS2018003), Key Scientific Research Projects of Colleges and Universities in Henan Province (grant no. 19B430008), and National Natural Science Foundation of China (grant no. 51801171).

Conflicts of Interest: The authors declare no conflict of interest.

\section{References}

1. Chagnon, M.; Guy, L.G.; Jackson, N. Evaluation of magnesium-based medical devices in preclinical studies: Challenges and points to consider. Toxicol. Pathol. 2019, 47, 390-400. [CrossRef] [PubMed]

2. Rahim, M.; Ullah, S.; Mueller, P. Advances and challenges of biodegradable implant materials with a focus on magnesium-alloys and bacterial infections. Metals 2018, 8, 532. [CrossRef]

3. Haude, M.; Ince, H.; Abizaid, A.; Toelg, R.; Lemos, P.A.; von Birgelen, C.; Christiansen, E.H.; Wijns, W.; Neumann, F.; Kaiser, C.; et al. Safety and performance of the second-generation drug-eluting absorbable metal scaffold in patients with de-novo coronary artery lesions (BIOSOLVE-II): 6 month results of a prospective, multicentre, non-randomised, first-in-man trial. Lancet 2016, 387, 31-39. [CrossRef]

4. Ho, M.; Chen, C.; Wang, C.; Chang, S.; Hsieh, M.; Lee, C.; Wu, V.C.; Hsieh, I. The development of coronary artery stents: From bare-metal to bio-resorbable types. Metals 2016, 6, 168. [CrossRef]

5. Soleymani, F.; Emadi, R.; Sadeghzade, S.; Tavangarian, F. Bioactivity behavior evaluation of PCL-chitosan-nanobaghdadite coating on AZ91 magnesium alloy in simulated body fluid. Coatings 2020, 10, 231. [CrossRef]

6. Saadati, A.; Hesarikia, H.; Nourani, M.R.; Taheri, R.A. Electrophoretic deposition of hydroxyapatite coating on biodegradable Mg-4Zn-4Sn-0.6Ca-0.5Mn alloy. Surf. Eng. 2020, 36, 908-918. [CrossRef]

7. Dong, H.; Li, D.; Mao, D.; Bai, N.; Chen, Y.; Li, Q. Enhanced performance of magnesium alloy for drug-eluting vascular scaffold application. Appl. Surf. Sci. 2018, 435, 320-328. [CrossRef]

8. Zhang, D.; Liu, Y.; Liu, Z.; Wang, Q. Advances in antibacterial functionalized coatings on Mg and its alloys for medical use-A review. Coatings 2020, 10, 828. [CrossRef]

9. Elkaiam, L.; Hakimi, O.; Aghion, E. Stress corrosion and corrosion fatigue of biodegradable Mg-Zn-Nd-Y-Zr alloy in in-vitro conditions. Metals 2020, 10, 791. [CrossRef]

10. Song, C.; Yang, Y.; Zhou, Y.; Wang, L.; Zhu, S.; Wang, J.; Zeng, R.; Zheng, Y.; Guan, S. Electrochemical polymerization of dopamine with/without subsequent PLLA coating on Mg-Zn-Y-Nd alloy. Mater. Lett. 2019, 252, 202-206. [CrossRef] 
11. Liu, X.; Zhen, Z.; Liu, J.; Xi, T.; Zheng, Y.; Guan, S.; Zheng, Y.; Cheng, Y. Multifunctional MgF $2 /$ polydopamine coating on mg alloy for vascular stent application. J. Mater. Sci. Technol. 2015, 31, 733-743. [CrossRef]

12. Liu, J.; Zheng, B.; Wang, P.; Wang, X.; Zhang, B.; Shi, Q.; Xi, T.; Guan, S. Enhanced in vitro and in vivo performance of Mg-Zn-Y-Nd alloy achieved with APTES pretreatment for drug-eluting vascular stent application. ACS Appl. Mater. Interfaces 2016, 8, 17842-17858. [CrossRef] [PubMed]

13. Yuan, T.; Yu, J.; Cao, J.; Gao, F.; Zhu, Y.; Cheng, Y.; Cui, W. Fabrication of a delaying biodegradable magnesium alloy-based esophageal stent via coating elastic polymer. Materials 2016, 9, 384. [CrossRef] [PubMed]

14. Wang, P.; Liu, J.; Shen, S.; Li, Q.; Luo, X.; Xiong, P.; Gao, S.; Yan, J.; Cheng, Y.; Xi, T. In vitro and in vivo studies on two-step alkali-fluoride-treated $\mathrm{Mg}$-Zn-Y-Nd alloy for vascular stent application: Enhancement in corrosion resistance and biocompatibility. ACS Biomater. Sci. Eng. 2019, 5, 3279-3292. [CrossRef]

15. Hou, S.; Mi, L.; Wang, L.; Zhu, S.; Hu, J.; Ding, Q.; Guan, S. Corrosion protection of Mg-Zn-Y-Nd alloy by flower-like nanostructured $\mathrm{TiO}_{2}$ film for vascular stent application. J. Chem. Technol. Biotechnol. 2013, 88, 2062-2066.

16. Chen, S.; Guan, S.; Hou, S.; Wang, L.; Zhu, S.; Wang, J.; Li, W. Characterization and corrosion properties of Ti-O/HA composite coatings on Mg-Zn alloy. Surf. Interface Anal. 2011, 43, 1575-1580. [CrossRef]

17. Zhao, A.; Wang, Z.; Zhou, S.; Xue, G.; Wang, Y.; Ye, C.; Huang, N. Titanium oxide films with vacuum thermal treatment for enhanced hemocompatibility. Surf. Eng. 2014, 31, 898-903. [CrossRef]

18. Ramos-Corella, K.J.; Sotelo-Lerma, M.; Gil-Salido, A.A.; Rubio-Pino, J.L.; Auciello, O.; Quevedo-López, M.A. Controlling crystalline phase of $\mathrm{TiO}_{2}$ thin films to evaluate its biocompatibility. Mater. Technol. 2019, 34, 455-462. [CrossRef]

19. Lin, Z.; Zhao, Y.; Chu, P.K.; Wang, L.; Pan, H.; Zheng, Y.; Wu, S.; Liu, X.; Cheung, K.M.; Wong, T.; et al. A functionalized $\mathrm{TiO}_{2} / \mathrm{Mg}_{2} \mathrm{TiO}_{4}$ nano-layer on biodegradable magnesium implant enables superior bone-implant integration and bacterial disinfection. Biomaterials 2019, 219, 119372. [CrossRef]

20. Huang, N.; Yang, P.; Cheng, X.; Leng, Y.; Zheng, X.; Cai, G.; Zhen, Z.; Zhang, F.; Chen, Y.; Liu, X.; et al. Blood compatibility of amorphors titanium oxide films synthesized by ion beam enhanced deposition. Biomaterials 1998, 19, 771-776.

21. Hou, S. Solvothermal fabrication of $\mathrm{TiO}_{2}$ nanosheet films on degradable Mg-Zn alloys. Surf. Eng. 2016, 32, 745-749. [CrossRef]

22. Wang, J.; Wang, L.; Guan, S.; Zhu, S.; Ren, C.; Hou, S. Microstructure and corrosion properties of as sub-rapid solidification Mg-Zn-Y-Nd alloy in dynamic simulated body fluid for vascular stent application. J. Mater. Sci. Mater. Med. 2010, 21, 2001-2008. [CrossRef]

23. Kokubo, T.; Takadama, H. How useful is SBF in predicting in vivo bone bioactivity? Biomaterials 2006, 27, 2907-2915. [CrossRef] [PubMed]

24. Gao, F.; Hu, Y.; Li, G.; Liu, S.; Quan, L.; Yang, Z.; Wei, Y.; Pan, C. Layer-by-layer deposition of bioactive layers on magnesium alloy stent materials to improve corrosion resistance and biocompatibility. Bioact. Mater. 2020, 5, 611-623. [CrossRef] [PubMed]

25. Gu, X.N.; Guo, H.M.; Wang, F.; Lu, Y.; Lin, W.T.; Li, J.; Zheng, Y.F.; Fan, Y.B. Degradation, hemolysis, and cytotoxicity of silane coatings on biodegradable magnesium alloy. Mater. Lett. 2017, 193, 266-269. [CrossRef]

26. Guo, X.; Wang, X.; Li, X.; Jiang, Y.C.; Han, S.; Ma, L.; Guo, H.; Wang, Z.; Li, Q. Endothelial cell migration on poly(epsilon-caprolactone) nanofibers coated with a nanohybrid shish-kebab structure mimicking collagen fibrils. Biomacromolecules 2020, 21, 1202-1213. [CrossRef]

27. Yeh, H.I.; Lu, S.K.; Tian, T.Y.; Hong, R.C.; Lee, W.H.; Tsai, C.H. Comparison of endothelial cells grown on different stent materials. J. Biomed. Mater. Res. A 2006, 76, 835-841. [CrossRef]

Publisher's Note: MDPI stays neutral with regard to jurisdictional claims in published maps and institutional affiliations. 